\title{
Cloning, Expression, and Purification of a Pathogenesis-Related Protein from Oenanthe javanica and Its Biological Properties
}

\author{
Bo Ram Jo, ${ }^{a}$ Jung Min Yu, ${ }^{b}$ Sukil Jang, ${ }^{a}$ Jeong Won Ahn, ${ }^{a}$ Hyun Soo Kim, ${ }^{a}$ Eun A Seoung, ${ }^{a}$ \\ Hee Yong Park, ${ }^{c}$ Deuk Hee Jin, ${ }^{a}$ and Seong Soo Joo*,a \\ ${ }^{a}$ College of Life Science, Gangneung-Wonju National University; 7 Jukheon-gil, Gangneung, Gangwon 25457, Republic \\ of Korea: ${ }^{b}$ Huscion MAJIC R\&D Center; 331 Pangyo-ro, Seongnam, Gyeonggi 13488, Republic of Korea: and \\ ${ }^{c}$ College of Pharmacy, Chung-Ang University; 47 Heuksuk-ro, Dongjak-gu, Seoul 06911, Republic of Korea. \\ Received September 18, 2019; accepted October 18, 2019
}

Pathogenesis-related (PR) proteins are inducible and accumulated in plants upon pathogen challenge for survival. Interest in these proteins has arisen in many fields of research, including areas of protein defense mechanisms and plant-derived allergens. In this study, we cloned a PR protein gene (OJPR) from Oenanthe javanica, which consisted of $465 \mathrm{bp}$ with an approximate molecular mass of $16 \mathrm{kDa}$. The DNA and deduced amino acid sequences of OJPR were 87\% similar to Pimpinella brachycarpa PR-1 together with a glycinerich loop which is a signature motif of PR-10. In microarray analysis, OJPR-transfected Raw264.7 (OJPR $\left.{ }^{+}\right)$ upregulated high mobility group box 1 and protein kinase $\mathrm{C} \alpha$, and downregulated chemokine ligand 3 and interleukin $1 \beta$ which are all related to toll-like receptor 4 (TLR4) and inflammation. TAK-242 and PD98059 inhibited the activation by OJPR, suggesting that OJPR transduce TLR4-mediated signaling. Interestingly, OJPR increased anti-viral repertoires, including interferon (IFN) $\alpha$, IFN $\gamma$, OAS1, and Mx1 in CD4 ${ }^{+}$primary $T$ cells. Taken together, we concluded that OJPR may play a role in modulating host defense responses via TLR signal transduction and provide new insights into the therapeutic and diagnostic advantages as a potential bioactive protein.

Key words Oenanthe javanica; pathogenesis-related protein; toll-like receptor 4; Bet v1 domain; innate immunity; $\mathrm{CD}^{+} \mathrm{T}$ cell

\section{INTRODUCTION}

Naturally unsheltered plants are unable to escape from diverse stressful environments basically due to their immobility. Plants actively defend themselves against various attacks from extrinsic environment and ecosystems by producing and accumulating secondary metabolites and antipathogenic proteins. ${ }^{1)}$ Hypersensitive reaction to pathogens (fungi, bacteria, and viruses) in plants is one of the major immune defense mechanisms, which triggers the expression of numerous plant genes encoding defense proteins. ${ }^{2,3)}$ Among these, pathogenesis-related (PR) proteins, which are classically divided into five families and further categorized into 17 families in accordance with their properties and functions, play an important role in inducing strong self-defense systems by getting accumulated in intercellular parts and vacuoles. ${ }^{4,5)}$ Plantderived PR proteins are mostly identified as acid-soluble, low molecular weight and protease-resistant molecules which helps the plants to survive in fastidious intracellular conditions. ${ }^{4)}$ Most of the PR proteins exhibit antifungal, antibacterial, insecticidal, nematicidal, and antiviral activity, whereas some exhibit enzymatic functions like $\beta$-1,3-glucanase or chitinase activities. ${ }^{6-8)}$

Until date, for the first time, we have cloned and expressed PR-1 like protein from leaves of Oenanthe javanica, a perennial member of the Oenanthe genus in Apiaceae family. Experimental papers have reported that the secondary metabolites from $O$. javanica possess various pharmacological and biological activities such as antioxidant, anti-inflammatory, anti-viral (anti-hepatitis B virus), and neuroprotective activi- ties. ${ }^{9-12)}$ PR proteins are known as one of the major sources of plant-derived allergens which induce allergenic response mediated by immunoglobulin E (IgE)-mediated allergy. ${ }^{13)}$ On the other hand, PR-1 protein is known to exhibit antifungal activity against various plant pathogenic fungi but their molecularlevel mechanisms are not clearly known. ${ }^{14)}$

In this study, we assessed the biological properties of PR-1 like protein from $O$. javanica (OJPR) and further provided the probable antipathogenic mechanism of action triggered by OJPR and its pharmacological intervention.

\section{MATERIALS AND METHODS}

Preparation of $O$. javanica cDNA Library and Selection of OJPR Leaves of $O$. javanica were collected from a stream of Gyeonggi, Republic of Korea. After washing with tap water, leaves were homogenized by TissueLyser II (Qiagen, MD, U.S.A.) and total RNA was extracted using easy-spin ${ }^{\mathrm{TM}}$ IIp Plant RNA Extraction kit (iNtRON, Gyeonggi, Republic of Korea) according to the manufacturer's instruction. The RNA quality and quantity were measured using UV/Vis spectrophotometer (MECASYS, Daejeon, Republic of Korea). Full-length cDNA library of $O$. javanica was constructed by an improved PCR-based oligo-capping method using pCNS-D2 vector system. The pretreated total RNA was ligated with $0.4 \mu \mathrm{g}$ of RNA oligonucleotide linker $\left(5^{\prime}\right.$-AGC AUC GAG UCG GCC UUG UUG GCC UAC UGG-3') using T4 ligase (New England Biolabs, MA, U.S.A.). After the completion of oligo-capping reactions, mRNAs were isolated by Oligotex Mini Kit (Qiagen). First-strand cDNA synthesis was 
performed with the Improm-II reverse transcription system from the purified mRNA in a total volume of $20 \mu \mathrm{L}$ (Promega, WI, U.S.A.). Subsequently, the amplified PCR products were digested with $S f i \mathrm{I}$, and cDNAs longer than $1.3 \mathrm{~kb}$ were ligated into DraIII-digested pCNS-D2 in an orientation-defined manner. The ligated cDNA was then transformed into Escherichia coli Top 10F' (Invitrogen, CA, U.S.A.) by electroporation (Gene Pulser II, BioRad, CA, U.S.A.). The constructed cDNA libraries were normalized as described previously. ${ }^{15)}$ OJPR genes were obtained from the colony PCR that was randomly performed using the cDNA library and the PCR products were cloned using the plasmid pGEM ${ }^{\circledR} T$ (Promega). Plasmid DNA was then sequenced with an ABI DNA sequencer (Applied Biosystems, CA, U.S.A.) and aligned in the Basic Local Alignment Search Tool (BLAST). Typically, 87\% sequence was identified as identical to Pimpinella brachycarpa PR-1. All the isolated total plasmids were digested with EcoRI and NotI to recheck the size of the insert.

Subcloning and Expression of OJPR The OJPR cDNA was subcloned into a BL21 expression vector (pET32a) to express the OJPR product. In brief, the OJPR cDNA was PCR-amplified using the upstream and downstream primers including NcoI and XhoI (upstream, 5'-CCA TGG GTG TTC AGA GCC AT-3', downstream, 5'-CCT CAT TGCCAACTACCTCGA G-3'). The amplified DNA was digested with $\mathrm{NcoI}$ and $\mathrm{XhoI}$, and further subcloned into the NcoI- and XhoI-digested pET32a to generate a recombinant plasmid pET32a-OJPR. The subcloned DNA in the pET32aOJPR was confirmed by PCR and DNA sequencing. The expression of the OJPR was confirmed with a His6 epitope sequence at the $3^{\prime}$ end of pET32a plasmid. BL21 was transformed to ampicillin resistance with pET32a-OJPR vector. The transformants were picked from the Luria-Bertani (LB) solid agar plates which contained ampicillin $(100 \mu \mathrm{g} / \mathrm{mL})$, and inoculated into LB liquid media containing ampicillin $(100 \mu \mathrm{g} / \mathrm{mL})$, followed by incubation at $37^{\circ} \mathrm{C}$ overnight in a shaking incubator $(200 \mathrm{rpm})$. Next, the cells were harvested when $\mathrm{OD}_{600}$ value was 1.0 , at the point when the cells resuspended in LB medium started induction by addition of varying concentration of isopropyl-f-L-thiogalactopyranoside (IPTG) for up to $24 \mathrm{~h}$. After optimal induction, the lysed cell pellets were electrophoresed on a $10 \%$ sodium dodecyl sulfate (SDS)-polyacrylamide gel to detect the target protein, and saved at $-80^{\circ} \mathrm{C}$ until further use. The proteins were visualized after staining with $0.01 \%$ Coomassie-blue staining and Western blot. The fusion protein was isolated using the MagneHis $^{\mathrm{TM}}$ Protein Purification System (Promega), which selectively purifies the polyhistidine-tagged protein.

Construction of Raw264.7.OJPR ${ }^{+}$and Anti-OJPR Production Plasmid DNA containing OJPR genes was digested by EcoRI and XhoI followed by the insertion of OJPR genes in the mammalian expression vector, pcDNA3.1(+). Subsequently, the pcDNA3.1(+).OJPR was transformed into $E$. coli $(\mathrm{DH} 5 \alpha)$ and plated on an LB agar plate containing ampicillin $100 \mu \mathrm{g} / \mathrm{mL}$ and incubated overnight. The transformants were picked from the LB solid agar plates, inoculated into LB liquid media containing ampicillin $(100 \mu \mathrm{g} / \mathrm{mL})$ and further incubated at $37^{\circ} \mathrm{C}$ overnight in a shaking incubator $(200 \mathrm{rpm})$. The subcloned pcDNA3.1(+).OJPR was confirmed by PCR and DNA sequencing. RAW264.7, a murine macrophage cell line, was cultured in Dulbecco's Modified Eagle's Medium
(DMEM) (Hyclone, UT, U.S.A.) supplemented with 10\% fetal bovine serum, $100 \mathrm{U} / \mathrm{mL}$ penicillin, and $100 \mu \mathrm{g} / \mathrm{mL}$ streptomycin (Invitrogen) at $37^{\circ} \mathrm{C}$ in a $5 \% \mathrm{CO}_{2}$-humidified incubator. The day before transfection, RAW264.7 cells were trypsinized, counted, and seeded in 6 well plates at the appropriate density $\left(4 \times 10^{5}\right.$ cells $\left./ \mathrm{mL}\right)$. When cells were $80 \%$ confluent, the culture medium was changed to serum-free DMEM, and the pcDNA3.1(+).OJPR was transfected with RAW264.7 using PolyFect ${ }^{\circledR}$ Transfection Reagent kit (Qiagen) and cultured for $24 \mathrm{~h}$. G418 $(500 \mu \mathrm{g} / \mathrm{mL})$ (Promega), an inhibitor of cell elongation, was treated for 4 weeks until positive clones were selected. The successful transfection was confirmed by a conventional PCR and the purified OJPR was used directly to produce polyclonal rabbit antibodies (Cosmogenetech, Seoul, Republic of Korea). For high-titer antibody, OJPR as an antigen was immunized, followed by boosting (3 times over 10 weeks), and a total of $30 \mathrm{~mL}$ OJPR specific antiserum was obtained.

Microarray Biotinylated cRNAs were prepared according to the standard Affymetrix protocol employing $500 \mathrm{ng}$ total RNA from lipopolysaccharide (LPS)-treated Raw264.7 and Raw264.7.OJPR cells (Affymetrix, CA, U.S.A.). After fragmentation, $15 \mu \mathrm{g}$ of aRNA was hybridized for $16 \mathrm{~h}$ at $45^{\circ} \mathrm{C}$ on GeneChip Mouse Genome Array (Affymetrix). GeneChips were washed and stained in the Affymetrix Fluidics Station 450. Then, GeneChips were scanned using the Affymetrix GeneChip Scanner 3000 7G. The data were analyzed with RMA (Robust Multi-array Analysis) using Affymetrix default analysis settings and global scaling as normalization method. The trimmed mean target intensity of each array was arbitrarily set to 100 . The normalized and log-transformed intensity values were analyzed using GeneSpring GX 12.5 (Agilent Technologies, CA, U.S.A.). Fold change filters included the requirement that the genes should be present in at least $200 \%$ of controls for up-regulated genes and lower than $50 \%$ of controls for down-regulated genes. Hierarchical clustering data were clustered grouped that behaved similarly across experiments using GeneSpring GX 12.5 (Agilent Technologies). A clustering algorithm was Euclidean distance, average linkage.

Toll-Like Receptor Signaling For toll-like receptor 4 (TLR4) signaling, Raw264.7 cells were seeded at a density of $1.2 \times 10^{6}$ cells per well in 12-well plates and pre-incubated at $37^{\circ} \mathrm{C}$ for $3 \mathrm{~h}$ to achieve stable attachment. Next, the wells were washed with 1X phosphate-buffered saline (PBS), refreshed with FBS-free DMEM, and treated with LPS $(1 \mu \mathrm{g} / \mathrm{mL})$ or OJPR ( 1 , and $5 \mu \mathrm{g} / \mathrm{mL}$ ) for $24 \mathrm{~h}$ and $1 \mu \mathrm{g} / \mathrm{mL}$ TLR4 inhibitor (TAK-242, Invivogen, CA, U.S.A.) was used to assess the reaction of OJPR with TLR4. TLR4-dependent genes and nitric oxide (NO) which were led by nuclear factor $-\kappa \mathrm{B}(\mathrm{NF}-\kappa \mathrm{B})$, were analyzed by real-time qPCR and Griess reagent, respectively (Sigma-Aldrich).

PCR Quantitative real-time PCR (qPCR) reactions were run on a Rotor-Gene 6000 instrument (Qiagen) using a SensiMix $^{\mathrm{TM}}$ SYBR HiROX kit (Bioline, London, U.K.) in $20 \mu \mathrm{L}$ reaction mixtures. Each real-time PCR master mix contained $10 \mu \mathrm{L}$ of $2 \mathrm{X}$ enzyme mastermix, $7 \mu \mathrm{L}$ of ribonuclease (RNase) free water, $1 \mu \mathrm{L}$ of each primer $(10 \mathrm{pM}$ each), and $1 \mu \mathrm{L}$ of the diluted template. PCR was performed with an initial pre-incubation step for $15 \mathrm{~min}$ at $95^{\circ} \mathrm{C}$, followed by 45 cycles of $95^{\circ} \mathrm{C}$ for $15 \mathrm{~s}$, annealing at $52^{\circ} \mathrm{C}$ for $15 \mathrm{~s}$, and extension at $72^{\circ} \mathrm{C}$ for $10 \mathrm{~s}$. Melting curve analysis was used to confirm formation of 
the expected PCR products, and products from all assays were electrophoresed on a $1.2 \%$ agarose gel to confirm the expected lengths. An inter-run calibrator was used and a standard curve was created for each gene to obtain PCR efficiencies. Relative sample expression levels were calculated using Rotor-Gene 6000 Series Software 1.7, expressed relative to $\beta$-actin, and corrected for between-run variability. Data are expressed as fold-change compared with the internal control gene. The primers for target genes (cyclooxygenase (COX)-2, inducible nitric oxide synthase (iNOS), CD80, MIP-2, tumor necrosis factor (TNF)- $\alpha$, TLR2, TLR4, CD80, interferon (IFN)- $\gamma$, IFN- $\alpha$, oligoadenylate synthetase 1 (OAS1), and Mx1) are listed in Table 1 (Bioneer, Daejeon, Republic of Korea).

Western Blotting Cells were lysed in 1\% RIPA (radioimmunoprecipitation assay) buffer containing protease and phosphatase inhibitors (Roche, Mannheim, Germany) and whole cell lysates were separated on a 10\% SDS-polyacrylamide gel electrophoresis (PAGE). After electrophoresis, proteins were transferred onto polyvinylidene difluoride (PVDF) (BD Bioscience, CA, U.S.A.) membranes and the membranes were blocked with $5 \%$ skim milk in Tris-buffered saline solution containing $0.1 \%$ Tween-20. The membrane was then immunoblotted with primary antibodies, anti-phospho-I $\kappa$ B-alpha, anti-phospho-Akt, and anti-beta-actin ( $\beta$-actin) (Santa Cruz Biotechnology, CA, U.S.A.), followed by incubation with horseradish peroxidase-conjugated anti-rabbit or anti-mouse secondary antibodies (Cell Signaling Technology, MA, U.S.A.). Blots were developed using enhanced chemiluminescence (ECL) solution (BD Bioscience).

Dual-luciferase Assay Raw264.7 cells were cultured in a 96-well microplate at a concentration of $8 \times 10^{4}$ cells per well. Each well was co-transfected with $200 \mathrm{ng}$ pGL4.32[luc2P/NF- $\kappa$ B-RE/Hygro] plasmid (Promega) and 2 ng pRL-SV40 plasmid (Promega). After $24 \mathrm{~h}$, cells were treated with LPS $(1 \mu \mathrm{g} / \mathrm{mL})$ or OJPR $(5 \mu \mathrm{g} / \mathrm{mL})$ for $6 \mathrm{~h}$ and compared with the control group that was pre-incubated with a TAK-242 $(5 \mu \mathrm{g} / \mathrm{mL})$ for $6 \mathrm{~h}$. The culture media were removed, and cells were washed with PBS. Lysis buffer was added into each well, and the plate was incubated by shaking for $5 \mathrm{~min}$ at room temperature. Relative luciferase activity was measured with a dual-luciferase reporter assay kit (Bioassay, CA, U.S.A.). A $50 \mu \mathrm{L}$ volume of cell lysate was transferred to an opaque white multi-well plate and $100 \mu \mathrm{L}$ of reconstituted Firefly luciferase (FFL) was added to each well. Luminescence was measured on a luminometer at $565 \mathrm{~nm}$. Then, $100 \mu \mathrm{L}$ reconstituted $R e$ nilla $(\mathrm{RL})$ reagent was added to each well, and the plate was gently tapped to mix the solutions. Luciferase luminescence was measured on a luminometer at $480 \mathrm{~nm}$.

Confocal Microscopy The transfected or non-transfected cells were seeded in a four-well chamber slide and treated with OJPR $(5 \mu \mathrm{g} / \mathrm{mL})$ in the presence or absence of LPS $(1 \mu \mathrm{g} / \mathrm{mL})$ for $16 \mathrm{~h}$. The cultured cells were fixed in $4 \%$ paraformaldehyde in $0.1 \mathrm{M}$ PBS for $15 \mathrm{~min}$ and incubated with permeabilization buffer consisting of $0.25 \%$ Triton X-100 (Sigma-Aldrich) in PBS for $10 \mathrm{~min}$ at room temperature (RT). Blocking was performed with $1 \%$ bovine serum albumin (BSA, Sigma-Aldrich) for $30 \mathrm{~min}$ at RT. Primary antibody (specific for OJPR) was then added to $1 \%$ BSA in PBS and incubated for $2 \mathrm{~h}$ at RT. Cells were washed three times with PBS before the addition of Alexa fluor 488-conjugated anti-rabbit immunoglobulin $\mathrm{G}(\mathrm{IgG})(\mathrm{H}+\mathrm{L}), \mathrm{F}\left(\mathrm{ab}^{\prime}\right) 2$ fragment (Cell Signaling) was added to $1 \% \mathrm{BSA}$ and incubated for $1 \mathrm{~h} 30 \mathrm{~min}$ at

Table 1. Sequences of the Real-Time Polymerase Chain Reaction Primers

\begin{tabular}{|c|c|c|c|c|}
\hline Gene & Direction & Sequence $\left(5^{\prime}\right.$ to $\left.3^{\prime}\right)$ & Size & Accession \\
\hline \multirow[t]{2}{*}{ iNOS } & Forward & 5'-TGCCCCTGGAAGTTTCTCTT & 252 & M 87039 \\
\hline & Reverse & 5'-ACTGCCCCAGTTTTTGATCC & & \\
\hline \multirow[t]{2}{*}{ IL-6 } & Forward & 5'-TCCATCCAGTTGCCTTCTTG & 165 & J 03783 \\
\hline & Reverse & 5'-CCACGATTTCCCAGAGAACA & & \\
\hline \multirow[t]{2}{*}{$\mathrm{COX} 2$} & Forward & 5'-GTCTGGTGCCTGGTCTGATG & 228 & NM_011198 \\
\hline & Reverse & 5'-GGTTGAAAAGGAGCTCTGGG & & \\
\hline \multirow[t]{2}{*}{$\mathrm{TNF} \alpha$} & Forward & 5'-AGCACAGAAAGCATGATCCG & 291 & NM_013693 \\
\hline & Reverse & 5'-GTTTGCTACGACGTGGGCTA & & \\
\hline \multirow[t]{2}{*}{$\mathrm{CD} 80$} & Forward & 5'-TATTGCTGCCTTGCCGTTAC & 181 & XM_017316858.1 \\
\hline & Reverse & 5'-ACCAGGCCCAGGATGATAAG & & \\
\hline \multirow[t]{2}{*}{ MIP2 } & Forward & 5'-TTCCATTGCCCAGATGTTGT & 239 & NM_009140 \\
\hline & Reverse & 5'-CTGTGTGGGTGGGATGTAGC & & \\
\hline \multirow[t]{2}{*}{ TLR2 } & Forward & 5'-TCAGTGGCCAGAAAAGATGC & 213 & XM_006501460.3 \\
\hline & Reverse & 5'-ACCAGCAACACAGGGAACAA & & \\
\hline \multirow[t]{2}{*}{ TLR4 } & Forward & 5'-CGCTCTGGCATCATCTTCAT & 192 & NM_021297.3 \\
\hline & Reverse & 5'-TGTTTGCTCAGGATTCGAGG & & \\
\hline \multirow[t]{2}{*}{$\mathrm{IFN} \alpha$} & Forward & 5'-ACCTGCAAGGCTGTCTGATG & 203 & NM_010502.2 \\
\hline & Reverse & 5'-CAGTCTTCCCAGCACATTGG & & \\
\hline \multirow[t]{2}{*}{$\operatorname{IFN} \gamma$} & Forward & 5'-GTGACATGAAAATCCTGCAG & 180 & NM_008337.4 \\
\hline & Reverse & 5'-GTTGTTGACCTCAAACTTGG & & \\
\hline \multirow[t]{2}{*}{ Mx1 } & Forward & 5'-GAGAGGCAAAGTCTCCTATG & 176 & NR_003520.1 \\
\hline & Reverse & 5'-GTCAATGAGAGTCAGGTCTG & & \\
\hline \multirow[t]{2}{*}{ OAS1 } & Forward & 5'-CCAGAATCTATGCCATCCTC & 169 & XM_006530330.4 \\
\hline & Reverse & 5'-CTCCTTACACAGTTGGTACC & & \\
\hline \multirow[t]{2}{*}{$\beta$-Actin } & Forward & 5'-TCCTGACCCTGAAGTACCCC & 262 & NM_031144 \\
\hline & Reverse & 5'-ATGCCAGTGGTACGACCAGA & & \\
\hline
\end{tabular}




\begin{tabular}{l}
\hline OJPR cDNA sequence (465 bp) \\
\hline ATGGGTGTTCAGAGCCATGTTCTTGAGCTCACTTCCTCACTCTCAGCAGAGAAAATGTTCCAGGGC \\
TTAGTCATTGATGCTGATACAATCATCCCCAAGGCTGCCCCTGGAGCTTACAAGAGTGTCGAGGTCA \\
AAGGAGACGGTGGAGCTGGAACCATAAAAAACATCACTCTGCCTGAAGGTAGCCCAATCACCACAA \\
TGACCCTGAGGACTGATGCAGTAAATAAGGAGGCATTGACATTCGATTACAGTGTCATCGACGGAG \\
ACATCCTGTTGGGCTTCATTGATCCATCGAAAACCATCTCGTAATTGTACCAACTGCTGATGGAGGT \\
AGCATTACCAAGACCACAGCCATATTCCACACCAAAGGCGATGCCGTAGTTCCTGAAGAGAACATC \\
AAGTATGCCAATGAGCAGAACACTGCTCTTTCAAGGCTATCGAGGCCCACCTCATTGCCAACTAA \\
\hline OJPR amino acid sequence (154-amino acids) \\
\hline \\
M G V Q S H V L E L T S S L S A E K M F Q G L V I D A D T I I P K A A P G A Y K S V E V K G D G G A \\
G T I K N I T L P E G S P I T T M T L R T D A V N K E A L T F D Y S V I D G D I L L G F I E S I E N H L V \\
I V P T A D G G S I T K T T A I F H T K G D A V V P E E N I K Y A N E Q N T A L F K A I E A H L I A N \\
\hline (bold: glycine-rich loop on the conserved domain)
\end{tabular}

Fig. 1. The Protein-Coding Sequence of OJPR Genes

Bold represents the glycine-rich loop (GXGGXGXXK motif) on conserved Bet_v1-like.

\begin{tabular}{|c|c|}
\hline Betv1 & 1 GVFNYETEATSVIPAARMFKAFILDGDKLVPKVAPQAISSVENIEGNGGPGTIKKINFPE \\
\hline \multirow{2}{*}{ OJPR } & 1 GVQSHVLELTSSLSAEKMFQGLVIDADTIIPKAAPGAYKSVE-VKGDGGAGTIKNITLPE \\
\hline & 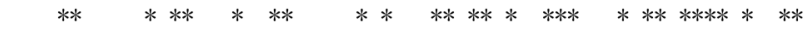 \\
\hline & 61 GFPFKYVKDRVDEVDHTNFKYNYSVIEGGPVGDTLEKISNEIKIVATPDGGCVLKISNKY \\
\hline \multirow{2}{*}{ OJPR } & 60 GSPITTMTLRTDAVNKEALTFDYSVIDGDILLGFIESIENHLVIVPTADGGSITKTTAIF \\
\hline & 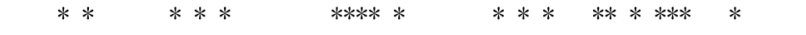 \\
\hline Betv1 & 121 HTKGNHEVKAEQVKASKEMGETLLRAVESYLLAH \\
\hline OJPR & 120 HTKGDAVVPEENIKYANEQNTALFKAIEAHLIAN \\
\hline
\end{tabular}

Fig. 2. Sequence Alignment of Birch Pollen Allergen Bet v1 with OJPR

Bet $\mathrm{vl}$ domain is highlighted with open box and the identical sequences are marked with an asterisk.

RT. The cells were rinsed and counterstained with propidium iodide (PI, Assay Designs, MI, U.S.A.) for $10 \mathrm{~min}$, followed by two PBS washes. Cells were examined with a confocal laser microscope (Olympus FV300, Tokyo, Japan) using two lasers, an argon-ion laser emitting at $488 \mathrm{~nm}$ and a HeNe laser emitting at $543 \mathrm{~nm}$ to excite Alexa-flour and PI, respectively, at a magnification of X1600. Two photomultipliers and photodetectors were used for visualization.

Immunocytochemistry (ICC) To assess the biological potential of OJPR in a receptor-mediated pathway, cells were prepared, fixed, and analyzed by fluorescence for acquiring productive high-resolution images. In brief, the cultured cells were fixed in $4 \%$ paraformaldehyde (in $1 \times \mathrm{PBS}$ ) for $15 \mathrm{~min}$, washed twice with $1 \times$ PBS supplemented with $100 \mathrm{mM}$ glycine for $5 \mathrm{~min}$, and incubated with a permeabilization buffer consisting of $0.1 \%$ Triton X-100 (Sigma-Aldrich) in $1 \times$ PBS for $30 \mathrm{~min}$ at room temperature. Blocking was performed with $1 \%$ BSA (Sigma-Aldrich) for $30 \mathrm{~min}$ at room temperature. For the performance of ICC, OJPR rabbit polyclonal antibody was added to $1 \%$ BSA in $1 \times$ PBS with Tween 20 and incubated for $2 \mathrm{~h}$ at room temperature. The cells were washed three times with $1 \times$ PBS before the addition of fluorescein isothiocyanate (FITC)-conjugated anti-mouse IgG 1:200 (Cell Signaling Technology) in 1\% BSA and incubated for $1 \mathrm{~h}$ at room temperature. Cultures were visualized with an inverted fluorescent microscope system (Eclipse Ti-S; Nikon, Tokyo, Japan) at a magnification of $\times 600$.

Statistical Analysis Data are expressed as means \pm standard error of the mean (S.E.M.). The statistical significance of differences between the groups was assessed using one-way ANOVA with Dunnet's post-hoc test. Statistical analyses were performed using SPSS v. 22 software package (SPSS, Inc., Chicago, IL, U.S.A.). A $p<0.05$ was considered significant.

\section{RESULTS}

Cloning, Isolation, and Characterization of OJPR Total RNAs isolated from $O$. javanica was re-purified to remove genomic DNA and small nucleic acids were degraded before cDNA library synthesis. From the cloned cDNA, the size of inserts was checked using pCNS-D2 vector and it was found that the size of cDNAs was less than $1 \mathrm{~kb}(0.5$ to $0.8 \mathrm{~kb})$ (data not shown). From the sequential analysis of colonies, we found $87 \%$ similar sequences to P. brachycarpa PR-1 in the Basic Local Alignment Search Tool (BLAST) and 465 base pairs were estimated which presumably coded for 154-amino acids with an approximate molecular mass of $16 \mathrm{kDa}$ (Fig. 1). The PR-1 like genes from $O$. javanica (OJPR) contained pathogenesis-related protein Bet v1 family with the glycine-rich loop domain, GDGGA GTIK ${ }^{16,17)}$ (Fig. 2). There was no putative signal peptide within this sequence, but the nearly conserved glycine-rich loop (G-X-G-G-X-G) with an ability to perform essential roles as antimicrobial agents in response to pathogen attack, was identified. ${ }^{18)}$ PR-1 proteins were first reported to be expressed in tobacco and to respond to tobacco mosaic virus infection. ${ }^{19)}$ In addition, it has been reported that an allergen, Cuc m 3 identified in muskmelon comprised of PR-1 protein family and may evoke oral allergy syndrome, while Bet v1 is associated with allergic rhinoconjunctivitis and asthma. ${ }^{20}$ Regardless of the existence of Bet v1 domain, the complementary defense functions of OJPR with exclusive pharmacological activities are of immense interest. 


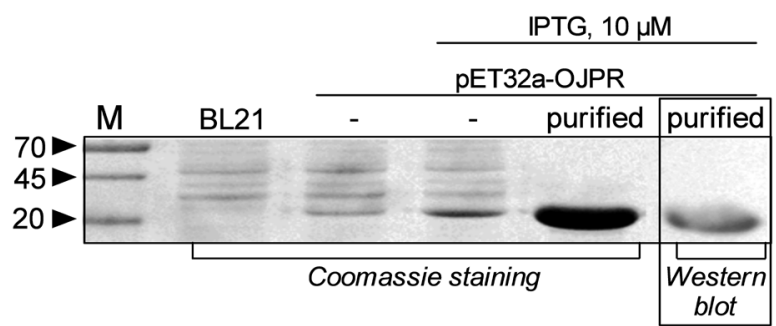

Fig. 3. SDS-PAGE and Western Blot Analysis of OJPR Expressed in BL21

OJPR expression was induced by $10 \mu \mathrm{M}$ IPTG in BL21 containing OJPR and pET32a-OJPR. Cells were lysed and OJPR was purified. The His-tag purified proteins were visualized by staining with $0.01 \%$ Coomassie brilliant blue G250 and probed with an anti-His-tag primary antibody for Western blot analysis, respectively.

Expression of OJPR in BL21 The OJPR cDNA was subcloned in the pET32a expression vector to generate recombinant plasmid pET32a-OJPR. The subcloned pET32a-OJPR was confirmed by enzyme digestion, PCR, and DNA sequencing analysis (data not shown). BL21 containing pET32a-OJPR was cultured in the presence of IPTG to induce the expression of OJPR proteins. Subsequently, pellets and their culture supernatants were analyzed by SDS-PAGE. While a weak protein band was observed in cell pellets from BL21 without IPTG, BL21 overproduced OJPR protein upon induction by $10 \mu \mathrm{M}$ IPTG for $6 \mathrm{~h}$ (Fig. 3). As the histidine (His)-tag is composed of 6 His, we expected that the target protein (OJPR) would be larger than that of $16 \mathrm{kDa}$ including an additional His-tag $(>1 \mathrm{kDa})$. Data demonstrated that no protein band was observed in BL21 containing pET32a control vector, whereas pET32a-OJPR well expressed the target protein $(>16 \mathrm{kDa})$, which corresponded to the estimated molecular weight of OJPR. To confirm the expression of His-tagged OJPR from pET32a, OJPR was immunoblotted with anti-His6 antibody and the results indicated high expression of OJPR in the system.

OJPR Gene Expression and Confocal Observation in Raw264.7 Cells The PR proteins exist in intercellular and vacuole parts of the plant and play a crucial role in protecting themselves from various attacks including physical, chemical, and biological stress along with phenolic compounds and phytoalexins. ${ }^{21)}$ To investigate the biological properties of the proteins in a mammalian cell, OJPR was transfected in Raw264.7 cells, a murine macrophage-like cell line, and successful gene and protein expression via PCR and confocal observation were assessed. Figure 4A clearly shows that OJPR-transfected Raw264.7 cells $\left(\mathrm{OJPR}^{+}\right)$well expressed the OJPR gene compared to non-transfected Raw264.7 cells $\left(\mathrm{OJPR}^{-}\right)$. Confocal observation confirmed that OJPR was intracellularly expressed in both presence and absence of LPS, whereas OJPR cells did not express OJPR, indicating that the construction of $\mathrm{OJPR}^{+}$cell system was well progressed and satisfied for the mammalian analysis of OJPR (Fig. 4B).

Profiles of Microarray Analysis DNA microarray technology allows the simultaneous measurement of the mRNA levels of thousands of genes. The array consists of a highly ordered matrix of thousands of different DNA sequences that can be used to measure DNA and RNA variations in applications that include gene expression profiling, comparative genomics, and genotyping. Consequently, we examined screening of microarray-based gene expression patterns and
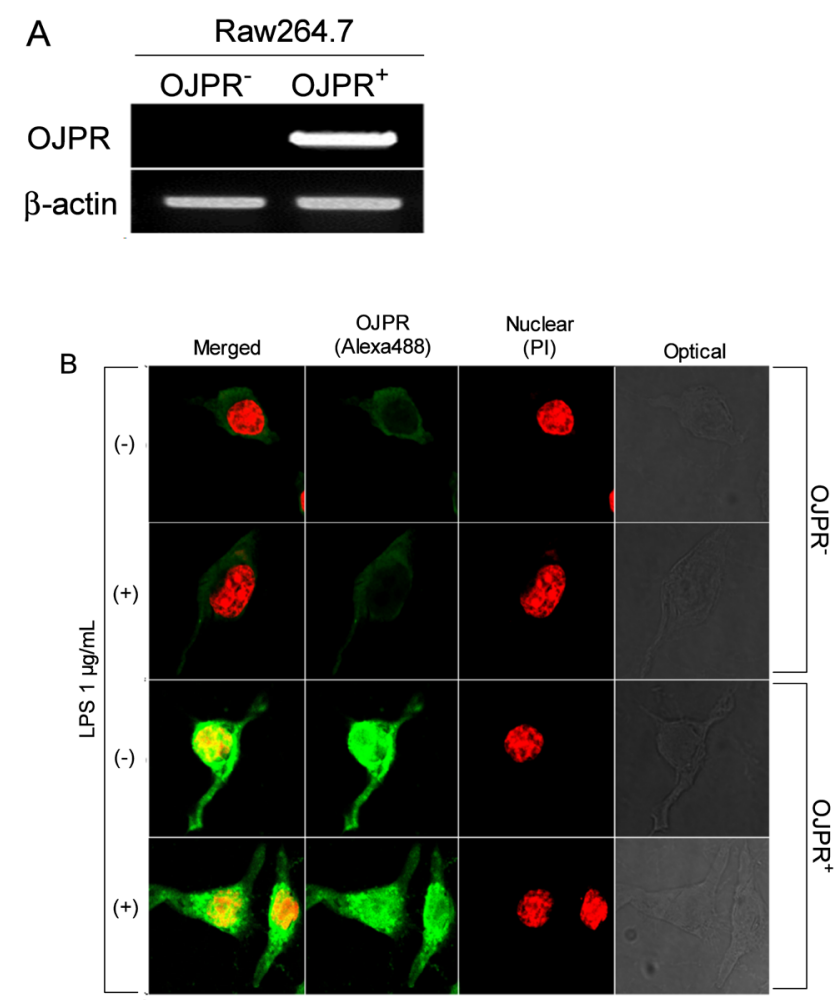

Fig. 4. OJPR Gene Expression and Confocal Imaging in Raw264.7 Cells

(A) $\mathrm{OJPR}^{-}$and $\mathrm{OJPR}^{+}$cells were cultured and reverse transcription-polymerase chain reaction was performed to confirm the transient transfection of OJPR. (B) Confocal fluorescence microscopy of $\mathrm{OJPR}^{-}$and $\mathrm{OJPR}^{+}$Raw264.7 cells after treatment with LPS. OJPR ${ }^{+}$cells remarkably expressed the target protein even in the absence of LPS. (Color figure can be accessed in the online version.)

insight into transcriptional processes along with biological mechanisms. Obtained data demonstrated that 1868 genes were upregulated and 876 genes were downregulated out of total 2744 genes. Of these, inflammation-related genes, such as High mobility group box 1 (HMGB 1), Protein kinase C- $\alpha$ (PKC- $\alpha$ ), Insulin-like growth factor binding protein 4 (IGFBP 4), and Nucleoporin 85 were markedly overexpressed (Table 2). Notably, HMGB1, a nuclear protein that can bind to DNA and act as a co-factor for gene transcription, has been reported to initiate innate immune response by activating multiple cell surface receptors, such as RAGE (receptor for advanced glycation endproducts), TLR-2, and TLR-4. ${ }^{22-24)}$ In addition, PKC- $\alpha$, which is a family of protein serine/threonine kinase, plays a role in intracellular signal transduction in association with TLR-2 pathways. $^{25)}$ The microarray results creditably indicate that OJPR may activate cells via TLR-mediated signaling pathways. On the contrary, chemokine ligand 3 (CCL3), which is involved in the acute inflammatory state, ${ }^{26)}$ and IL- $1 \beta$, a key mediator of the inflammatory response essentially for the host-response and resistance to pathogens, ${ }^{27)}$ were remarkably down-expressed compared with those from LPS-treated OJPR ${ }^{-}$. Data suggested that OJPR expressed in macrophages may downregulate excessive activation of acute inflammatory responses when attacked by pathogens by either controlling the production of IL- $1 \beta$, a potent inflammasomedependent cytokine ${ }^{28)}$ or probably blocking TLR4-triggered CCL3 enhancement. ${ }^{29)}$

LPS-Induced Intracellular Responses in $\mathrm{OJPR}^{+}$To investigate potent cell signaling of OJPR along with recep- 
Table 2. A Partial List of Inflammatory Response-Related Genes by OJPR Identified in the Microarray Experiments

\begin{tabular}{|c|c|c|c|c|}
\hline Gene description & Accession no. & OJPR.LPS/N.LPS intensity & N.LPS signal value & OJPR.LPS signal value \\
\hline \multicolumn{5}{|l|}{ Over-expression } \\
\hline High mobility group box 1 & NM_010439 & 9.52 & 15.35 & 146.06 \\
\hline Protein kinase $\mathrm{C}$, alpha & NM_011101 & 5.76 & 10.24 & 59.00 \\
\hline Insulin-like growth factor binding protein 4 & NM_010517 & 5.20 & 8.01 & 41.68 \\
\hline Nucleoporin 85 & NM_0010012292 & 5.08 & 38.22 & 193.97 \\
\hline \multicolumn{5}{|c|}{ Down-expression* } \\
\hline Chemokine (C-X-C motif) ligand 3 & NM_203320 & 61.68 & 306.78 & 4.97 \\
\hline Interleukin 1 beta & NM_008361 & 22.03 & 281.79 & 12.79 \\
\hline Lymphocyte antigen 86 & NM_010745 & 18.15 & 124.81 & 6.88 \\
\hline Chemokine (C-C motif) ligand 5 & NM_013653 & 16.46 & 4028.82 & 244.72 \\
\hline Interleukin 1 alpha & NM_010554 & 12.78 & 65.25 & 5.11 \\
\hline Fc receptor, $\operatorname{IgG}$, high affinity I & NM_010186 & 11.71 & 66.05 & 5.64 \\
\hline CD40 antigen & NM_011611 & 6.48 & 290.52 & 44.83 \\
\hline Interleukin 1 family, member 6 & NM_019450 & 5.85 & 61.58 & 10.52 \\
\hline
\end{tabular}

*Normalized intensity ratio between comparative and control group (inversed number).
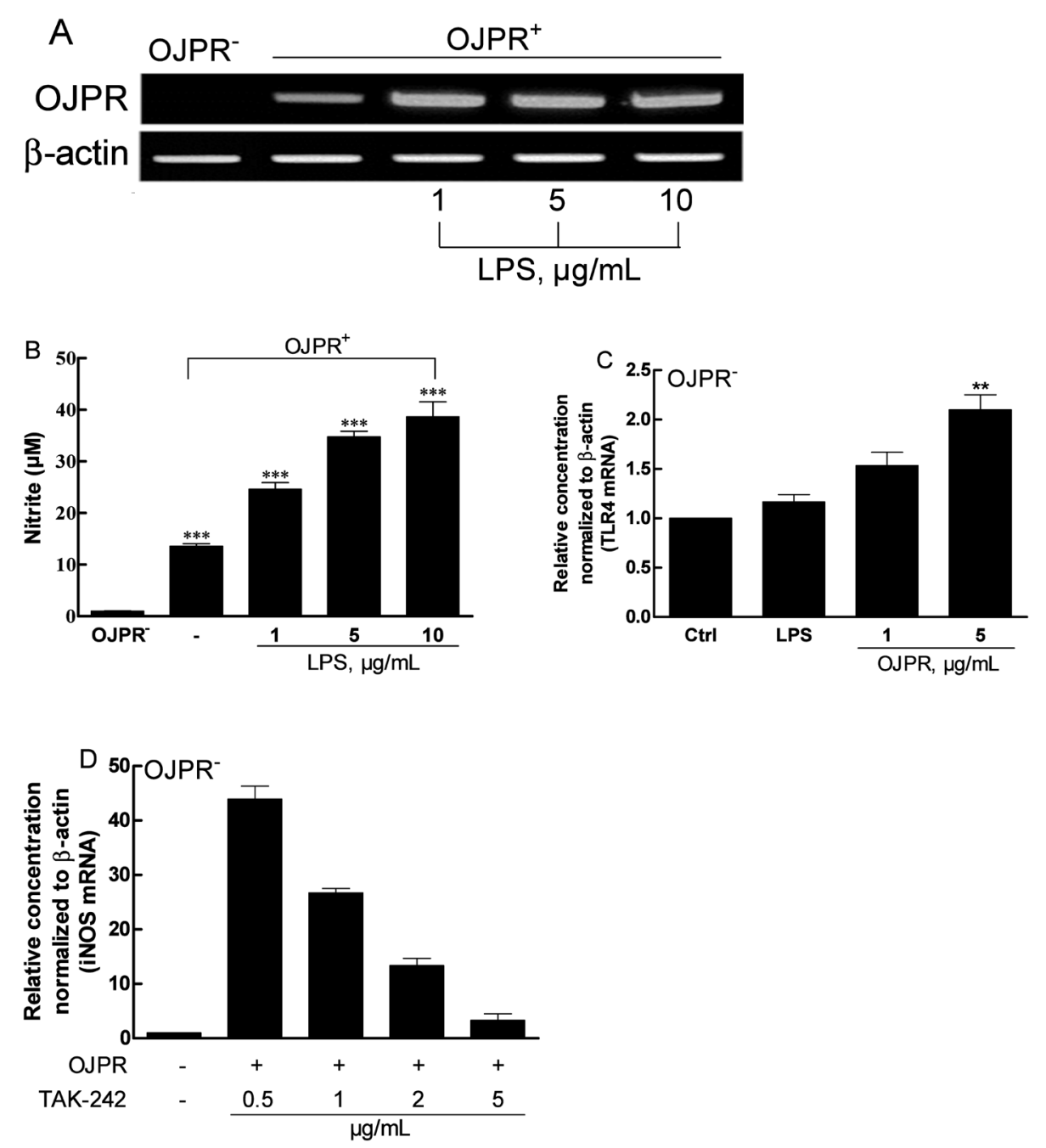

Fig. 5. RT-PCR and qPCR Analysis of OJPR Gene Transcription

OJPR gene expression (A) and NO production (B) were compared with OJPR ${ }^{+}$after culture. The expression of TLR4 (C) and iNOS (D) genes confirmed their involvement in TLR signal pathways. TAK-242 was used as a selective TLR4 inhibitor. Results are expressed as means \pm standard deviations (S.D.) from three separate experiments. $* * p<0.01,{ }^{* * *} p<0.001 v s$. control.

tor-mediated signal transduction, $\mathrm{OJPR}^{+}$was transiently expressed and TLR4-dependent cytokines were evaluated in the presence or absence of LPS. Data well demonstrated that $\mathrm{OJPR}^{+}$highly expressed OJPR genes intracellularly, and the expression was remarkably escalated in the presence of LPS (Fig. 5A). Interestingly, nitric oxide (NO) production 

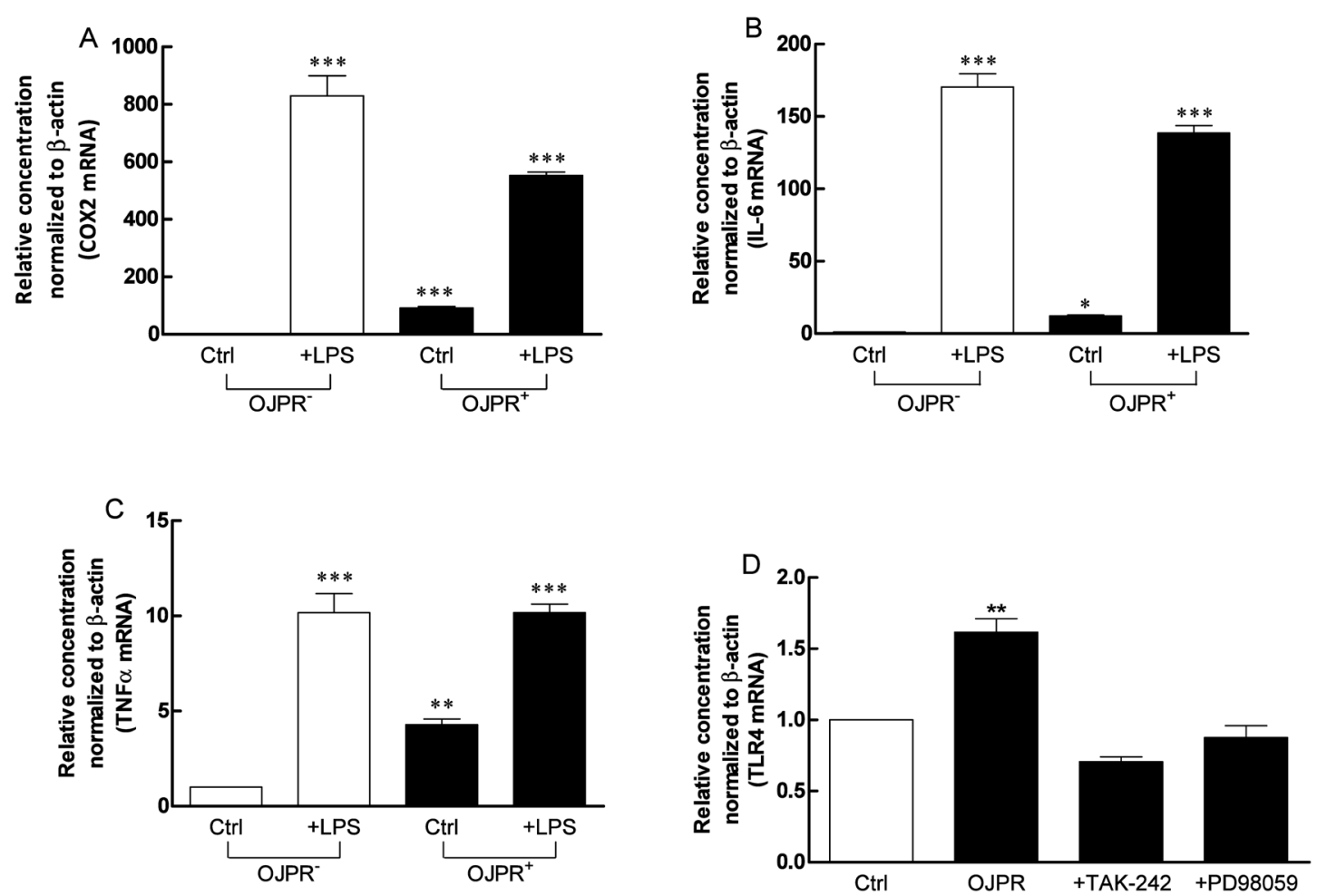

Fig. 6. Profiles of TLR4-Dependent Gene Expression

COX2 (A), IL-6 (B), and TNF $\alpha$ (C) were analyzed in both OJPR ${ }^{-}$and OJPR ${ }^{+}$Raw264.7 cells in the presence or absence of LPS. TLR4/Myd88-dependency was proposed by treating with TAK242 $(5 \mu \mathrm{g} / \mathrm{mL})$ and PD98059 $(150 \mu \mathrm{M})$ in the level of TLR4 mRNA (D). Results are expressed as means \pm S.D. from three separate experiments. $* p<0.05 * * p<0.01, * * * p<0.001$ vs. control (leftmost).

was dose-dependently increased when treated with LPS (1 to $10 \mu \mathrm{g} / \mathrm{mL}$ ) in $\mathrm{OJPR}^{+}$, while LPS-free $\mathrm{OJPR}^{+}$increased NO production 10-fold higher compared to OJPR ${ }^{-}$(Fig. 5B). Moreover, OJPR directly increased TLR4 gene expression, indicating its close relation to TLR4 pathway (Fig. 5C). This finding coincided with a significant decrease in the expression of iNOS when $\mathrm{OJPR}^{+}$were pre-treated with TLR4 inhibitor, TAK-242 that selectively binds to Cys747 of TLR4 and thus interferes with protein-protein interactions between TLR4 and its adaptor molecules ${ }^{30)}$ (Fig. 5D). TAK-242 is a cyclohexane derivative that selectively suppresses TLR4 signaling, thus inhibiting the production of pro-inflammatory repertoires; the blockade of OJPR in the presence of TAK-242 may provide a clue between OJPR-TLR4 interaction. ${ }^{31)}$ Figures $6 \mathrm{~A}-\mathrm{C}$ demonstrate that OJPR alone stimulated TLR4-dependent genes, such as COX2, IL-6, and TNF $\alpha^{32,33)}$ that were escalated during the co-treatment with LPS. TAK-242 and MAP kinase kinases inhibitor, PD98059, also inhibited the production of TLR4 genes, indicating that OJPR was involved in TLR4/MyD88 signal cascades (Fig. 6D). However, it was unclear why LPSstimulated $\mathrm{OJPR}^{+}$cells did not express the TLR4-dependent genes as much as $\mathrm{OJPR}^{-}$cells. One possibility is that OJPR may act as an antioxidant enzyme, such as superoxide dismutase and/or catalase, whose activities are upregulated upon infection together with PR proteins. ${ }^{34)}$ In line with this, our data suggest that OJPR may participate in enhanced expression of TLR4-mediated signal transduction pathway. In future studies, more investigations are necessitated on the activation of TLR4/MyD88 signal transduction pathway which results in innate immune responses. ${ }^{35)}$

Signal Pathways of OJPR The canonical adaptor for inflammatory signaling pathways downstream of members of TLR and IL-1 receptor families, Myd88 was thought to be associated with OJPR signaling. In this regard, we hypothesized that OJPR binds to TLR4 followed by triggering by Myd88/NF- $\kappa$ B signaling pathway. ${ }^{36)}$ ICC observation represented that OJPR was primarily associated with TLR4 pathway when considering that OJPR was mostly inhibited by the TAK-242 (Fig. 7A). Consistently, CD80 and MIP2, which are directly associated with TLR4 signaling, were significantly inhibited in the presence of TAK-242 (Figs. 7B, C). Notably, OJPR was expected to be engaged in the activation of $\mathrm{I} \kappa \mathrm{B} \alpha$ and Akt, indicating its probable involvement in the mitogenactivated protein kinase (MAPK) signaling cascades and the phosphatidylinositol 3-kinase (PI3K) signaling pathway, thus playing a pivotal role in innate immune response and cell survival $^{37,38)}$ (Figs. 7D, E).

Activation of $\mathrm{CD4}^{+} \mathrm{T}$ Cells and TLR Involvement MyD88 is the essential adaptor for most of the TLRs and TLRs expressed in T cells have been reported to serve as costimulatory signals in T-cell activation. ${ }^{39-42)}$ In $\mathrm{CD}^{+}{ }^{+} \mathrm{T}$ cells, IFN $\alpha$ has been reported to be essential for the anti-viral effect (human immunodeficiency virus, HIV). Also, Type II interferon, IFN $\gamma$ has been reported to regulate the host immune response against viral and intracellular bacterial pathogens. ${ }^{43}$ Interestingly, OJPR remarkably escalated the expression of IFN $\gamma$ and IFN $\alpha$ compared to anti-CD3/anti-CD28-treated $\mathrm{CD}^{+} \mathrm{T}$ cells (Figs. 8A, B). In the present work, the IFNinducible antiviral genes, $2^{\prime} 5^{\prime} \mathrm{OAS} 1$ and myxovirus resistance proteins 1 (Mx1) were significantly increased in the presence of OJPR, in a dose-dependent manner (Figs. 8C, D). Moreover, TLR2 and TLR4 were significantly increased by OJPR (Figs. 8E, F), suggesting that IFN $\gamma$ expression in $\mathrm{CD}^{+} \mathrm{T}$ cells is related with the expression of TLR2 and TLR4, which are 

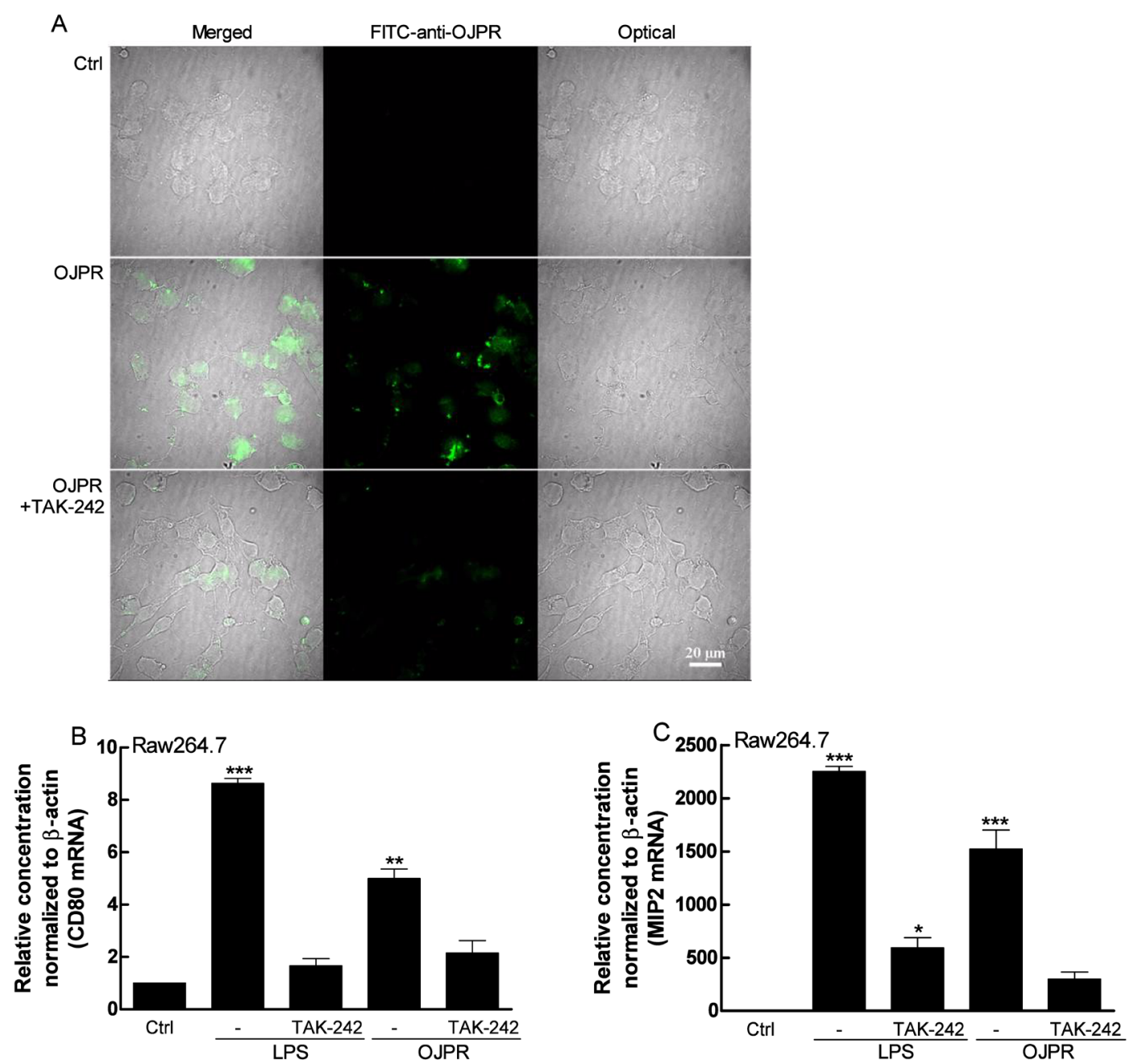

$E$
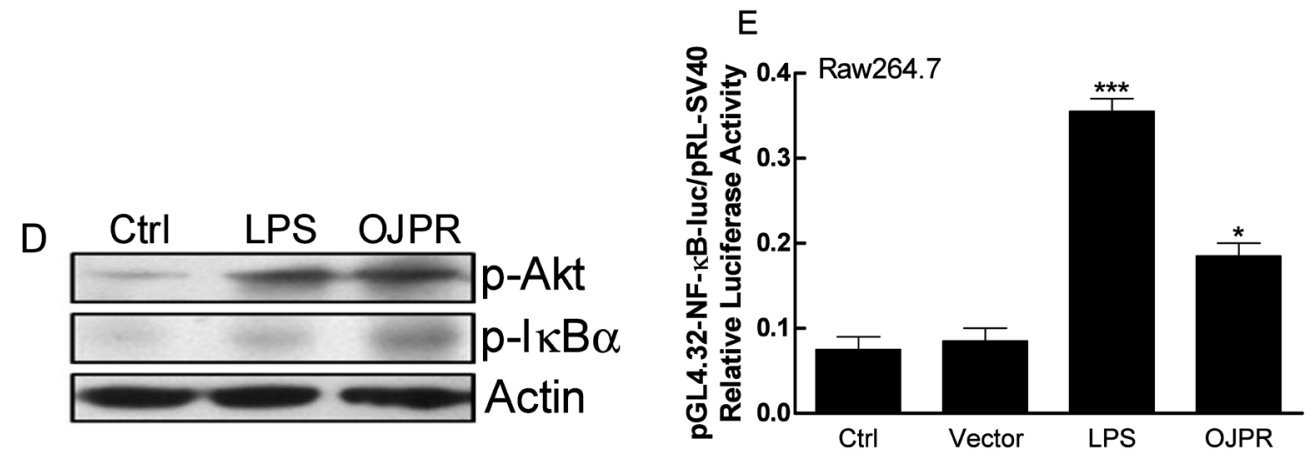

Fig. 7. Determination of TLR4 Implication in Immunocytochemistry and mRNA/Protein Analysis

The FITC-conjugated OJPR was treated in Raw264.7 cells for $24 \mathrm{~h}$ in the presence or absence of TAK-242 (A). CD80 (B) and MIP2 (C) genes were analyzed and compared with the expression of genes in OJPR and LPS-treated Raw264.7 cells. Expression of proteins associated with TLR4 signal pathways was assessed in Western blot analysis for p-Akt and $\mathrm{p}-\mathrm{I} \kappa \mathrm{Ba}$ (D) and pGL4.32-NF- $\kappa \mathrm{B}$ luciferase assay (E). Results are expressed as means \pm S.D. from three separate experiments. $* p<0.05 * * p<0.01$, $* * * p<0.001 v s$. control (leftmost). (Color figure can be accessed in the online version.)

located in the cell membranes with extracellular domains that recognize appropriate ligands.

\section{DISCUSSION}

In this study, we have identified $O$. javanica PR protein, OJPR, which exhibited $87 \%$ similarity to $P$. brachycarpa PR-1 sequences along with the inclusion of PR-10 allergen, Bet $\mathrm{v}$ 1-like birch pollen, without putative IgE binding residues. Basically, OJPR was identified to comprise of 154-amino acids with a molecular mass of $16 \mathrm{kDa}$ and included 6 conserved $\mathrm{IgE}$ residues forming disulfide bridges and a compact 3-dimensional structure, which are typical structural properties of PR-1 protein. OJPR predicted to have synergistic biological activity by containing PR-1 and PR-10 molecular moiety without allergenic potential. PR proteins are universally located in almost all the plant organs and especially present abundantly in the leaves. ${ }^{5)}$ Physiologically, PR proteins are up-regulated by various environmental factors including pathogen attacks and also dependent on certain internal stimuli essential for 

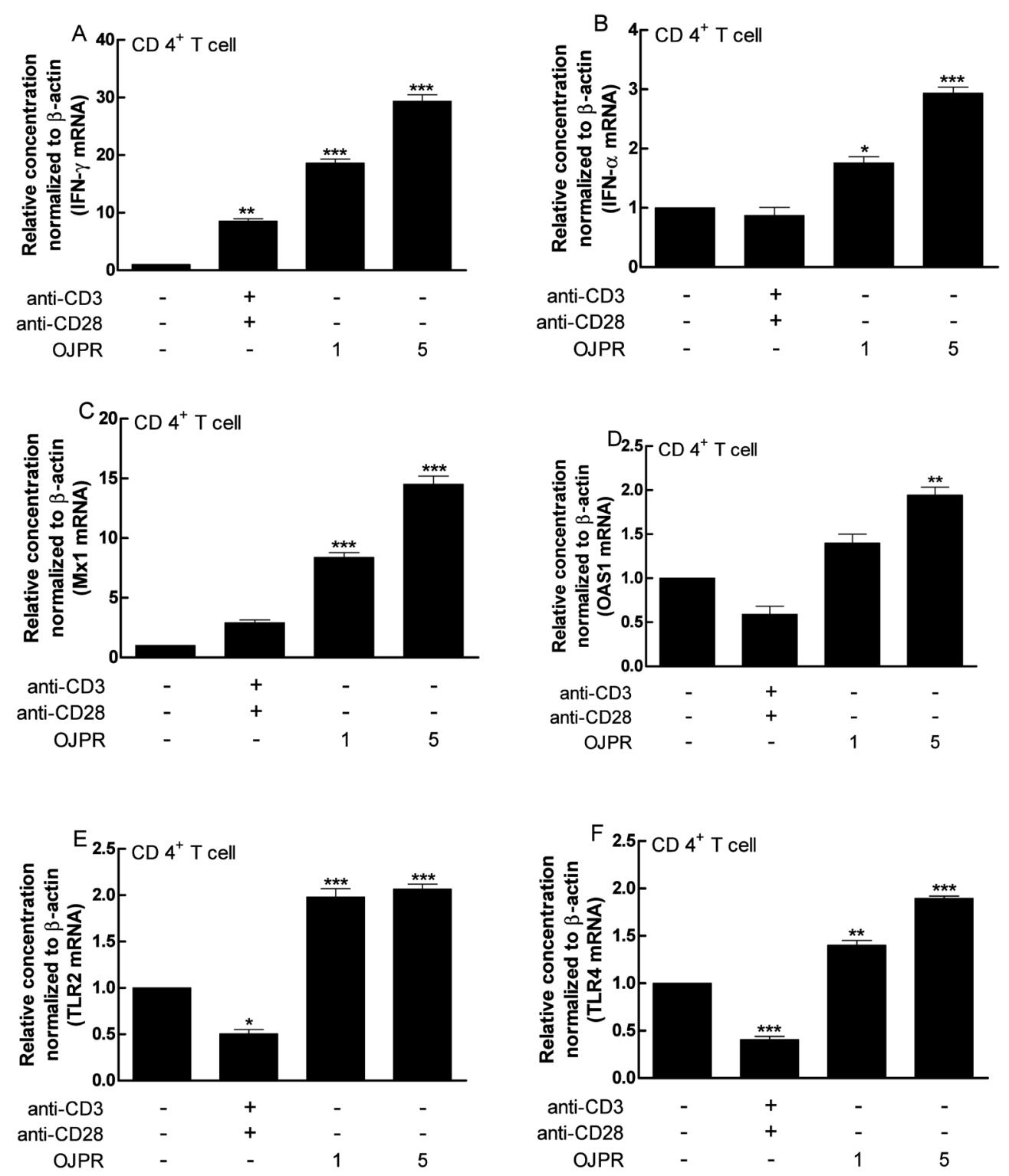

Fig. 8. Interferon-Inducible Gene Profiles in $\mathrm{CD}^{+}{ }^{+} \mathrm{T}$ Cells

$\mathrm{CD}^{+}$cells were isolated from mouse spleens and activated with anti-CD3/anti-CD28 monoclonal antibodies ( $1 \mu \mathrm{g} / \mathrm{mL}$ each). mRNAs were isolated from the harvested $\mathrm{CD}^{+}$cells $24 \mathrm{~h}$ after the culture and cDNA was synthesized for qPCR analysis. IFN- $\gamma$ (A), IFN- $\alpha$ (B), Mx1 (C), and OAS (D) mRNAs were analyzed to define the association with interferon-inducible antiviral activity. TLR2 (E) and TLR (F) mRNAs were additionally investigated to speculate the TLR-mediated viral recognition by OJPR in $\mathrm{CD}^{+} \mathrm{T}$ cells. Results are expressed as means \pm S.D. from three separate experiments. $* p<0.05 * * p<0.01, * * * p<0.001$ vs. control (leftmost).

development. ${ }^{44,45)}$ Inducible expression of genes for host defense has known to be mediated by obvious mechanisms, including transcriptional elongation, histone modifications, and nucleosome remodeling. ${ }^{46)}$ Notably, $\mathrm{OJPR}^{+}$macrophages led to overexpression of HMGB1 gene that interacts with nucleosomes, transcription factor, and histones, suggesting that the existence of OJPR within the cell may impart biological potentiality in both innate immune reaction and inflammationmediated pathogenesis as a therapeutic modulator. ${ }^{47,48)}$ Moreover, marked inhibition of OJPR activity by TLR4 and MAP kinase kinases inhibitor (TAK-242 and PD98059) strongly indicated that OJPR can act as a modulator for TLR4/MyD88 signal cascades. On the contrary, OJPR significantly increased the anti-viral repertoires, including IFN $\gamma, \operatorname{IFN} \alpha, \mathrm{OAS} 1$, and $\mathrm{Mx} 1$ which are directly associated with anti-viral responses in $\mathrm{CD}^{+}$primary $\mathrm{T}$ cells. Nonetheless, it remains to be elucidated more about the OJPR under the eukaryote expression system which includes post-transcriptional modification to reach their final structure by molecular chaperones. ${ }^{49)}$

In summary, our data demonstrated that the newly identified and expressed OJPR may possess the biological activity and play a role in modulating host defense responses via TLR signal cascades together with anti-viral activities. Finally, we propose that these findings will provide novel insights into the therapeutic and diagnostic advantages of OJPR with additive roles in the control of gene expression and receptor-mediated signal pathways.

Acknowledgments This study was supported by Gangneung-Wonju National University.

Conflict of Interest The authors declare no conflict of interest. 


\section{REFERENCES}

1) Pusztahelyi T, Holb IJ, Pócsi I. Secondary metabolites in fungusplant interactions. Front. Plant Sci., 6, 573 (2015).

2) Stintzi A, Heitz T, Prasad V, Wiedemann-Merdinoglu S, Kauffmann S, Geoffroy P, Legrand M, Fritig B. Plant 'pathogenesis-related' proteins and their role in defense against pathogens. Biochimie, 75, 687-706 (1993).

3) Agrios GN. Plant Pathology, 4th ed., Academic Press, San Diego, pp. 93-114 (1997).

4) Van Loon LC. Pathogenesis-related proteins. Plant Mol. Biol., 4, 111-116 (1985)

5) Van Loon LC, Van Strien EA. The families of pathogenesis-related proteins, their activities, and comparative analysis of PR-1 type proteins. Physiol. Mol. Plant Pathol., 55, 85-97 (1999).

6) Kombrink E, Schröder M, Hahlbrock K. Several "pathogenesisrelated" proteins in potato are 1,3-beta-glucanases and chitinases. Proc. Natl. Acad. Sci. U.S.A., 85, 782-786 (1988).

7) Heitz T, Segond S, Kauffmann S, Geoffroy P, Prasad V, Brunner F, Fritig B, Legrand M. Molecular characterization of a novel tobacco pathogenesis-related (PR) protein: a new plant chitinase/lysozyme. Mol. Gen. Genet., 245, 246-254 (1994).

8) Caruso C, Caporale C, Chilosi G, Vacca F, Bertini L, Magro P, Poerio E, Buonocore V. Structural and antifungal properties of a pathogenesis-related protein from wheat kernel. J. Protein Chem., 15, 35-44 (1996).

9) Kwon D, Yoon S, Carter O, Bailey GS, Dashwood RH. Antioxidant and antigenotoxic activities of Angelica keiskei, Oenanthe javanica and Brassica oleracea in the Salmonella mutagenicity assay and in HCT116 human colon cancer cells. Biofactors, 26, 231-244 (2006).

10) Han YQ, Huang ZM, Yang XB, Liu HZ, Wu GX. In vivo and in vitro anti-hepatitis $\mathrm{B}$ virus activity of total phenolics from $\mathrm{Oe}$ nanthe javanica. J. Ethnopharmacol., 118, 148-153 (2008).

11) Ma CJ, Lee KY, Jeong EJ, Kim SH, Park J, Choi YH, Kim YC, Sung SH. Persicarin from water dropwort (Oenanthe javanica) protects primary cultured rat cortical cells from glutamate-induced neurotoxicity. Phytother. Res., 24, 913-918 (2010).

12) Kim TH, Ku SK, Bae JS. Persicarin is anti-inflammatory mediator against HMGB1-induced inflammatory responses in HUVECs and in CLP-induced sepsis mice. J. Cell. Physiol., 228, 696-703 (2013).

13) Woodfolk JA, Commins SP, Schuyler AJ, Erwin EA, Platts-Mills TA. Allergens, sources, particles, and molecules: Why do we make IgE responses? Allergol. Int., 64, 295-303 (2015).

14) Breen S, Williams SJ, Outram M, Kobe B, Solomon PS. Emerging insights into the functions of pathogenesis-related protein 1. Trends Plant Sci., 22, 871-879 (2017).

15) Soares MB, Bonaldo MF, Jelene P, Su L, Lawton L, Efstratiadis A. Construction and characterization of a normalized cDNA library. Proc. Natl. Acad. Sci. U.S.A., 91, 9228-9232 (1994).

16) Radauer C, Lackner P, Breiteneder H. The Bet v 1 fold: an ancient, versatile scaffold for binding of large, hydrophobic ligands. $B M C$ Evol. Biol., 8, 286 (2008).

17) Han JH, Lee JH, Lee OR. Leaf-specific pathogenesis-related 10 homolog, PgPR-10.3, shows in silico binding affinity with several biologically important molecules. J. Ginseng Res., 39, 406-413 (2015).

18) Cândido Ede S, Pinto MF, Pelegrini PB, Lima TB, Silva ON, Pogue R, Grossi-de-Sá MF, Franco OL. Plant storage proteins with antimicrobial activity: novel insights into plant defense mechanisms. FASEB J., 25, 3290-3305 (2011).

19) Cornelissen BJ, Hooft van Huijsduijnen RA, Van Loon LC, Bol JF. Molecular characterization of messenger RNAs for "pathogenesis related' proteins la, $\mathrm{lb}$ and lc, induced by TMV infection of tobacco. EMBO J., 5, 37-40 (1986).

20) Pirson F, Detry B, Pilette C. Occupational rhinoconjunctivitis and asthma caused by chicory and oral allergy syndrome associated with bet v 1-related protein. J. Investig. Allergol. Clin. Immunol., 19,
306-310 (2009)

21) Bowles DJ. Defense-related proteins in higher plants. Annu. Rev. Biochem., 59, 873-907 (1990).

22) Park JS, Arcaroli J, Yum HK, Yang H, Wang H, Yang KY, Choe KH, Strassheim D, Pitts TM, Tracey KJ, Abraham E. Activation of gene expression in human neutrophils by high mobility group box 1 protein. Am. J. Physiol. Cell Physiol., 284, C870-C879 (2003).

23) Müller S, Ronfani L, Bianchi ME. Regulated expression and subcellular localization of HMGB1, a chromatin protein with a cytokine function. J. Intern. Med., 255, 332-343 (2004).

24) Wu H, Ma J, Wang P, Corpuz TM, Panchapakesan U, Wyburn KR, Chadban SJ. HMGB1 contributes to kidney ischemia reperfusion injury. J. Am. Soc. Nephrol., 21, 1878-1890 (2010).

25) Asehnoune K, Strassheim D, Mitra S, Yeol Kim J, Abraham E. Involvement of PKCalpha/beta in TLR4 and TLR2 dependent activation of NF-kappaB. Cell. Signal., 17, 385-394 (2005).

26) Llorián-Salvador M, González-Rodríguez S, Lastra A, FernándezGarcía MT, Hidalgo A, Menéndez L, Baamonde A. Involvement of CC Chemokine Receptor 1 and CCL3 in Acute and Chronic Inflammatory Pain in Mice. Basic Clin. Pharmacol. Toxicol., 119, 32-40 (2016).

27) Dinarello CA. Biologic basis for interleukin-1 in disease. Blood, 87 , 2095-2147 (1996).

28) Amati A-L, Zakrzewicz A, Siebers R, Wilker S, Heldmann S, Zakrzewicz D, Hecker A, McIntosh JM, Padberg W, Grau V. Chemokines (CCL3, CCL4, and CCL5) inhibit ATP-induced release of IL-1 $\beta$ by monocytic cells. Mediators Inflamm., 2017, 1434872 (2017).

29) Weinstein SL, Sanghera JS, Lemke K, DeFranco AL, Pelech SL. Bacterial lipopolysaccharide induces tyrosine phosphorylation and activation of mitogen-activated protein kinases in macrophages. $J$. Biol. Chem., 267, 14955-14962 (1992).

30) Matsunaga N, Tsuchimori N, Matsumoto T, Ii M. TAK-242 (resatorvid), a small-molecule inhibitor of Toll-like receptor (TLR) 4 signaling, binds selectively to TLR4 and interferes with interactions between TLR4 and its adaptor molecules. Mol. Pharmacol., 79, 34-41 (2011).

31) Lin X, Kong J, Wu Q, Yang Y, Ji P. Effect of TLR4/MyD88 signaling pathway on expression of IL- $1 \beta$ and TNF- $\alpha$ in synovial fibroblasts from temporomandibular joint exposed to lipopolysaccharide. Mediators Inflamm., 2015, 329405 (2015).

32) Fukata M, Chen A, Klepper A, Krishnareddy S, Vamadevan AS, Thomas LS, Xu R, Inoue H, Arditi M, Dannenberg AJ, Abreu MT. Cox-2 is regulated by Toll-like receptor-4 (TLR4) signaling: Role in proliferation and apoptosis in the intestine. Gastroenterology, 131, 862-877 (2006).

33) Chen RJ, Yuan HH, Zhang TY, Wang ZZ, Hu AK, Wu LL, Yang ZP, Mao YJ, Ji DJ, Zhu XR. Heme oxygenase-2 suppress TNF- $\alpha$ and IL6 expression via TLR4/MyD88-dependent signaling pathway in mouse cerebral vascular endothelial cells. Mol. Neurobiol., 50, 971-978 (2014).

34) van Loon LC, Rep M, Pieterse CM. Significance of inducible defense-related proteins in infected plants. Annu. Rev. Phytopathol., 44, 135-162 (2006).

35) Zeuke S, Ulmer AJ, Kusumoto S, Katus HA, Heine H. TLR4-mediated inflammatory activation of human coronary artery endothelial cells by LPS. Cardiovasc. Res., 56, 126-134 (2002).

36) Deguine J, Barton GM. MyD88: a central player in innate immune signaling. F1000Prime Rep., 6, 97 (2014).

37) Yang Y, Lv J, Jiang S, Ma Z, Wang D, Hu W, Deng C, Fan C, Di S, Sun Y, Yi W. The emerging role of Toll-like receptor 4 in myocardial inflammation. Cell Death Dis., 7, e2234 (2016).

38) Gustin JA, Korgaonkar CK, Pincheira R, Li Q, Donner DB. Akt regulates basal and induced processing of NF-kappaB2 (p100) to p52. J. Biol. Chem., 281, 16473-16481 (2006).

39) Applequist SE, Wallin RP, Ljunggren HG. Variable expression of 
Toll-like receptor in murine innate and adaptive immune cell lines. Int. Immunol., 14, 1065-1074 (2002).

40) Liu G, Zhang L, Zhao Y. Modulation of immune responses through direct activation of Toll-like receptors to T cells. Clin. Exp. Immunol., 160, 168-175 (2010).

41) Kawai T, Akira S. Toll-like receptors and their crosstalk with other innate receptors in infection and immunity. Immunity, 34, 637-650 (2011)

42) Salem ML. Triggering of toll-like receptor signaling pathways in $T$ cells contributes to the anti-tumor efficacy of $\mathrm{T}$ cell responses. $\mathrm{Im}$ munol. Lett., 137, 9-14 (2011).

43) Audigé A, Urosevic M, Schlaepfer E, Walker R, Powell D, Hallenberger S, Joller H, Simon HU, Dummer R, Speck RF. Anti-HIV state but not apoptosis depends on IFN signature in CD4+ T cells. J. Immunol., 177, 6227-6237 (2006).

44) Yalpani N, Silverman P, Wilson TM, Kleier DA, Raskin I. Salicylic acid is a systemic signal and an inducer of pathogenesis-related proteins in virus-infected tobacco. Plant Cell, 3, 809-818 (1991).

45) Kasprzewska A. Plant chitinases-regulation and function. Cell. Mol. Biol. Lett., 8, 809-824 (2003).

46) Pope SD, Medzhitov R. GENE EXPRESSION. Unwinding inducible gene expression. Science, 352, 1058-1059 (2016).

47) Bianchi ME, Agresti A. HMG proteins: dynamic players in gene regulation and differentiation. Curr. Opin. Genet. Dev., 15, 496-506 (2005).

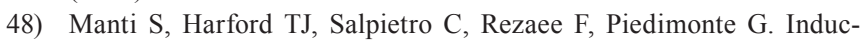
tion of high-mobility group Box-1 in vitro and in vivo by respiratory syncytial virus. Pediatr. Res., 83, 1049-1056 (2018).

49) Hartl FU, Hayer-Hartl M. Molecular chaperones in the cytosol: from nascent chain to folded protein. Science, 295, 1852-1858 (2002). 